\title{
Drosjenæring under lupen: kontrollpluralisme i praksis?
}

\author{
Av Paul Larsson ${ }^{1}$ og Vanja Lundgren Sørli ${ }^{2}$
}

\begin{abstract}
The article deals with attempts to regulate the Norwegian taxi industry. Over the past thirty years there has been periodic focus on different forms of tax-related crime during which counter measures in the form of regulation have been heavy in the taxi industry. Despite this the biggest complex of tax-related crimes and other forms of fraud ever detected in Norway was recently uncovered in the industry. This article asks and tries to explain why it is so difficult to regulate the taxi industry."
\end{abstract}

\section{Inledning}

Larsson tar opp sentrale utviklingstrekk innen »regulering « ${ }^{3}$ og kontroll av økonomisk kriminalitet i artikkelen »Det farlige noeringslivet. Reguleringen av økonomisk kriminalitet $i$ det 21 århundre « (2011). Han hevder at dagssituasjonen karakteriseres av kontroll-pluralisme: Strafferettslig, økonomisk og administrativ kontroll som griper inn i hverandre og til dels har overgripende felt og fokus. Kontrollen utføres av offentlige myndigheter, private/halvoffentlige organer, registre og bedrifters egenkontroll. »... [D]agens situasjon er preget av et mangfold og en kompleksitet innen reguleringen av økonomisk kriminalitet som forbigår mange kontrollteoretikeres verste drømmer«, hevdes det videre (Larsson 2011, s. 88).

Med dette som utgangspunkt tar vi her for oss en kriminogen næring, den norske drosjenæringen, og ser nærmere på hvordan regulering og kontroll er utviklet fra 1980-tallet fram til i dag. Hvordan kan utviklingen forståes ved hjelp av nyere kontrollteori? Konkret ser vi på »regulering« inkludert kriminalisering og »kontroll« i form av »policing« med overvåking av næring og næringsaktører.

Valget å studere utviklingen av regulering og kontroll av drosjenæringen har sammenheng med at flere næringsdrivende har vært under mistanke for og etterforskning av økonomisk kriminalitet i to tiår (Lundgren Sørli 2011, 2012). Sakene pågår i skrivende stund, den 10. mai 2012 slår Aftenposten under overskriften

* Title in English: Cheating in the Taxi-industry: On the limits of regulation 
»Ny gigantsiktelse mot drosjesvindler« opp at »etter fire år på rømmen i Pakistan, landet drosjesvindleren N.N. på Gardemoen, eskortert av norsk politi. Nå venter enda en rettssak « (2012:5). Aftenposten oppsummerer samtidig det de har kalt »drosjesvindelsaken « (se også Lundgren Sørli 2011 og 2012), og rekapitulerer med at 341 eiere og rundt 2000 sjåfører har vært involvert i svart kjøring og "svindel« med skatt og avgifter. »Status i saken er at over 200 eiere er dømt etter svart kjøring. I tillegg har 570 eiere og sjåfører mottatt over 100 millioner i trygd og sosialhjelp mens de kjørte svart. Over 100 av disse er dømt for trygdesvindel «, Aftenposten (2012:5). Det er liten tvil om at det er gjort en rekke økonomiske lovbrudd i næringen siden 1980-tallet. Man kan hevde at drosjenæringen, tross skiftende aktører og strukturer, er en næring med tradisjoner når det gjelder triksing og fusk.

Med utgangspunkt $\mathrm{i}$ en kort beskrivelse av skattelovbruddene i drosjenæringen kartlegges og drøftes reguleringen og kontrollen av næringen de siste 30 årene. Ved å kartlegge kontroll og reguleringssituasjonen i en konkret næring, søker vi å konkretisere utviklingen av det som har blitt en kompleks og mangfoldig kontroll og reguleringssituasjon. Men forsøkene på regulering av drosjenæringen gjennomført de siste tiårene danner også utgangspunkt for en noe videre analyse av utviklingen innen kontrollen av næringslivet. Utviklingen er langt fra så endimensjonal som man kan anta. Til tross for flere konkrete reguleringstiltak rettet mot næringen synes det fortsatt som det er mange muligheter for å omgå regelverket. Sett opp mot nyere kontrollteori kan man si at dette er et eksempel på omfordelingseffekter i praksis. Noen tydelige huller tettes, mens andre muligheter for fusk åpner seg. Artikkelen bygger på analyse av et kvalitativt materiale produsert i forbindelse med CSR-prosjektet »The meanings of economical crimes in the Norwegian Taxi-industry: Means for prevention? « som ble gjennomført i det sentrale norske Østlandsområdet i perioden 2006-10. Dataproduksjon og fortolkning redegjøres for av Lundgren Sørli (2011:94-99), 2012:190-91). Kort sagt består materialet av kvalitative dybdeintervjuer med drosjesjåfører, -eiere og representanter for administrasjon og ledelse innen to drosjesentraler, samt bakgrunnssamtaler med og observasjoner av drosjeaktører i arbeid gjennomført i forbindelse med et mindre feltarbeid. Videre består materialet av intervjuer med profesjonelle kontrollører som driver ulike former for polisiær virksomhet rettet mot drosjenæringen ${ }^{4}$ og andre aktører som er involvert i overvåking av næringen fordi de arbeider i næringsorganisasjoner eller innen myndighetsorganer som helt eller delvis har dette til oppgave. I tillegg til dette er det gjennomført en tekstanalyse av samtlige avisoppslag som er publisert i perioden 2005-09 i riksdekkende aviser om økonomiske lovbrudd i drosjenæringen (Lundgren Sørli 2012). I vår sam- 
menheng skal det påpekes at $116 \mathrm{av}$ de totalt 177 oppslagene var relatert til kontroll, noe som i seg selv forstås som at kontroll-tematikk står sentralt når massemedia omtaler økonomisk kriminalitet. Dette har etter vårt syn blant annet sammenheng med at kontrolletatene er sentrale informasjonskilder for media og viktige for mediafokuset på en rekke saker (Palm og Skogersson 2008). I tillegg har vi i forbindelse med inneværende arbeid gjennomført bakgrunnssamtaler med representanter for skatteetaten. Samtlige bakgrunnssamtaler kan karakteriseres som ustrukturerte kvalitative intervjuer der både intervjudeltaker og intervjuer har påvirket struktur, tematikk og innhold i intervjuet (Lundgren Sørli 2005), mens dybdeintervjuene kan betraktes som semistrukturerte (Lundgren Sørli 2011).

\section{Drosjenæringen som lovbruddsarena}

Drosjenæringen har de siste tiårene vært kjennetegnet av flere store skattesaker. Næringen har, ikke ufortjent, fătt et frynsete rykte. Her tar vi utgangspunkt i de mest bransjetypiske lovbruddene, å kjøre passasjerer eller gods uten at inntektene oppgis til beskatning. Inntektene skjules ofte for skattemyndigheter og annen inntektskontroll ved hjelp av »konsekvenslovbrudd« (Lundgren Sørli (2008), Disse lovbruddene har nærmest har blitt en tradisjon i drosjenæringen. Selv om modusene for å skjule svartkjøringa har skiftet og ulike virkemidler er tatt $\mathrm{i}$ bruk for å gjennomføre lovbruddene, har drosjeaktører kjørt svart så lenge inntekter fra drosjekjøring har vært skattepliktige. At det over tid også er gjort en rekke andre økonomiske lovbrudd i næringssammenheng er dokumentert blant annet av Lundgren Sørli (2011).

Ellingsen (1991: 146-163) beskriver med utgangspunkt i egenerfaring som deltids og i en periode heltidsdrosjesjåfør i årene fra 1977-1985 »en innenfraforståelse av en bransje og en yrkeskultur der svart arbeid står sentralt« (s. 147). Han diskuterer omfanget av svart kjøring i næringen ut fra eget og bekjente sjåførers og eieres perspektiv, viser til at det i perioden han kjørte kun var én drosjeeier som av drosjefolk var kjent for ikke å ville betale sjåfører svart og til en stikkprøvekontroll utført av skattemyndighetene i årene 1980-1982. Blant de kontrollerte drosjeeierne konkluderte skattemyndighetene med at bare var betalt skatt av $48 \%$ av realinntektene (s. 149). Ellingsen konkluderer med at på 1980-tallet var »den skattefrie ${ }^{5}$ virksomheten av avgjørende betydning i drosjenæringen«, og videre at »så godt som alle som er innom denne næringen vil komme i berøring med lovstridig virksomhet« (s. 150).

Flere i Lundgren Sørli sine undersøkelser $(2008,2011)$ forteller som Ellingsen om en »svart« relativt systematisert praksis som begynte tidligere enn 1980-tallet, i følge flere allerede da de mekaniske taksametrene ble tatt i bruk på 1950-tallet. 
»Drosjebiler hadde to (mekaniske) taksametre, det ene (hvite) oppgav man inntekter fra, det andre (svarte) oppgav man ikke innkjørt inntekt fra«. Taksametre ble skiftet med et håndgrep, og de fleste drosjebiler hadde til enhver tid to taksametre i bilen, det man ikke brukte lå i bagasjerommet. Hvilket apparat inntektene fra en »kjøring « ble registrert fra, var umulig for den alminnelige passasjer å oppdage (Lundgren Sørli 2011). Annet materiale bekrefter dette (Lundgren Sørli 2008). Å operere med to regnskap og to kasser for svart og hvit omsetning er også kjent fra andre yrker og næringer, blant annet fant Larsson dette i sin undersøkelse av frisørenes svarte økonomi (Larsson 1995).

Når drosjefolk viser tilbake til tida fram til 1994, peker de på at næringen var preget av organisert svart kjøring. En drosjeeier med 25 års erfaring i 2006 forteller: »Før 1994 hadde vi et taksametersystem som het AP-tax, og da het det populært at en med åtte tommeltotter, fire verkefingre og en skrutrekker kunne kjøre og betale skatt etter eget forgodtbefinnende. En kom seg ikke unna svartkjøring da!« Den intervjuede drosjeeieren og flere med ham peker imidlertid også på at det skjedde endringer i løpet av 1990-tallet. Et nytt (digitalt) taksametersystem ble påbudt innført i 1994 og kontroll med næringene ble satt på dagsorden. En annen drosjeeier forteller:

»Det var jo også store forskjeller på det som ble registrert inntjent på hver enkelt bileier, men poenget er at ETTER »amnestiet« på nittitallet, gikk inntekten vesentlig opp på alle som livnærte seg på drosjekjøring. Det betyr ikke at alle oppga alt da heller, men de oppga mer. Noen begynte også å kjøre helt hvitt, og har fortsatt med det.«

Kontrollsjefen ved Skatt Øst bekrefter dette. Før 1994 ble det utført en pilotstudie av næringen. Etter at næringen innførte digitale taksametre og skattemyndighetene lovte drosjeeierne i Oslo Taxi at økt innrapportert omsetting fra næringen ikke ville danne grunnlag for bokettersyn, ble en etterkontroll gjennomført. Denne viste økt omsetting jevnført med pilotstudien. I denne forbindelse ble drosjenæringen også pålagt systemer for registrering av innkjørte inntekter, ${ }^{6}$ oppbevaring av kvitteringer med mer. Trass økt regulering og fokus på lovbrudd i næringen sluttet man ikke å kjøre svart på 1990-tallet. Situasjonen fortsatte; enkelte kjørte hvitt, mange kjørte noe svart mens andre benyttet mer finurlige teknikker og holdt større summer unna beskatning. Drosjesvindelsaken startet med at skattekontrollører 17. juni 2003 innkalte vel 200 drosjeeiere til kjøretøykontroll på Tøyen i Oslo. 27 drosjeeiere kom dit med kortsluttede taksametre. Samtidig gjennomførte Økokrim og skatteetaten en ransakelse på kontoret til en regnskapsfører i Oslo som etter å ha vært medlem av Oslo Likningsnemnd hadde tilbudt regn- 
skapshjelp til drosjeeiere. Økokrim tok beslag i programvare til å forfalske regnskapsunderlag, spesialprintere til å produsere skiftlapper og 44 permer med falske regnskapsbilag. Det ble samme dag gjennomført to ransakelser til; en der regnskapsførerens klienter lagret sine regnskaper og en hjemme hos en av regnskapsførerens medhjelpere. En uke seinere ble en annen medhjelpers hjem ransaket. (Haakaas \& Sæter 2010).

Politiaksjonene som ble gjennomført i juni 2003 var »starten på opprullingen av Norges mest omfattende skattesvindelsak innenfor en og samme bransje. Hver fjerde drosjeeier i Oslo er på dette tidspunktet innblandet i saken.« skriver Einar Haakaas og Kjetil Sæter (2010). Den hovedmistenkte regnskapsføreren hadde drøyt tre hundre kunder tilknyttet ulike drosjesentraler i Oslo-regionen som drosjeeiere. Påfølgende etterforskning førte til at regnskapsføreren og medhjelpere ble tiltalt for brudd på Regnskapsloven og Ligningsloven, sammenholdt med Straffelovens $\S 62$, 1.1. De ble seinere dømt og straffet for forholdene, regnskapsføreren ble dømt til sju års fengsel av Oslo tingrett i 2006. I 2007 ble anken behandlet i Borgarting lagmannsrett og regnskapsførerens straff ble skjerpet til åtte års fengsel. Straffen, som på domstidspunktet var en av de strengeste som var idømt for økonomiske lovbrudd i Norge, ble seinere opprettholdt av Høyesterett. At lovbruddene var systematiske og organiserte begrunnet straffenivået.

Etter beslagene og etterforskningen av regnskapsføreren og hans medhjelpere, gransket skattemyndighetene de enkelte drosjeeieres innberetning av skatt. Konklusjonen var at vel 300 drosjeeiere hadde levert falsk likning, og flere hundre drosjesjåfører og -eiere hadde arbeidet svart. $\mathrm{NAV}^{7}$ og Oslo kommune etterforsket drosjenæringen og fant at drosjeeiere og sjåfører hadde mottatt trygd og sosiale ytelser ${ }^{8}$ på falskt grunnlag mens de kjørte svart. Vesentlig fler enn de dømt for skattelovbrudd har fătt straffeskatt og administrative avgjørelser ${ }^{9}$ rettet mot seg. Da næringen ble kontrollert i to faser på 2000-tallet, ble lovbrudd gjort i forbindelse med svart kjøring kartlagt, etterforsket og over 100 millioner NKR underslått skatt inndrevet.

\section{Drosjenæringen som kontroll- og reguleringsfelt}

Utvikling av regulering og kontroll av drosjenæringen må sees i sammenheng med utviklingen av den som arbeidsplass og marked. Fra 1980-tallet og framover har materielle, tekniske og reguleringsmessige endringer skjedd »i rivende fart « som en drosjeeier beskriver det når han forteller om utviklingen fra hans sjåførdager på slutten av 1970-tallet. Antallet biler i drosjetrafikk har steget betraktelig de siste 30 årene, både fordi etterspørselen etter drosjer er økt og fordi det er store endringer i markedssituasjonen. Den aller viktigste materielle og reguleringsmes- 
sige endringen er kanskje at monopolsituasjonen som eksisterte i de fleste byer og tettsteder til og med 1990-tallet er opphevet, som ledd i en europeisk deregulering av drosjenæringen i følge OECD (2007). Konkurrerende sentraler er etablert, i Oslo er det eksempelvis per i dag seks drosjesentraler i motsetning til den ene som dominerte Oslo-markedet med drosjemonopol til 1999.

\section{Regulering inkludert kriminalisering av handlinger gjort $i$ næringssammenheng}

Regulering innebærer her prosessene som resulterer i regelverk opprettet med sikte på å oppnå orden og utnevnelse av regulator som håndhever regelverket med reaksjoner eller sanksjoner når regelbrudd oppdages. Regulering kan komme til uttrykk i former av selvregulering internt i bedrifter/næringer og lovgivning med og uten strafferettslige sanksjoner. Kriminalisering blir følgelig en reguleringsvariant; lovgitt regelverk for akseptabel atferd der overtredelser eksplisitt er regulert med strafferettslige sanksjonsbestemmelser. Avgrensningen er gjort med basis i Clarke (2000) og Larsson (2011). Her er fokus satt på resultatet av prosessene; utformet regelverk og definerte håndhevere. Vi gir utvalgte eksempler på den reguleringen som har vært gjennomført i og med drosjenæringen de siste tiårene.

Toner (1997) inndeler den økonomiske reguleringen av drosjenæringen i tre ulike kategorier. En av disse er »adgangs vilkår«, det vil si betingelsene for å få delta i næringsvirksomhet. Disse er per 2011 regulert i Samferdselsloven ${ }^{10}$ og reguleringen settes ut i livet på lokalt plan. Regulatorer er ofte kommunale samferdselsetater og i siste instans politiet som utsteder kjøresedler og løyver. Historisk sett har den enkelte norske kommune hatt førerprøver og vurderinger av sjåfører og drosjeeiere der kompetansemålene har variert mellom kommuner og fylker, et system som fortsatt eksisterer til tross for at det bliver mer enhetlig.

Når det gjelder reguleringen av hvem som får bli drosjesjåfører ble standarden for Oslo satt allerede på 1930-tallet. Oslo Formannskap bestemte i møter av 3. juni 1931, 16. november 1932 og 22. februar 1933 at »den [sjåfør] som driver ervervsmessig personbefordring med motorvogner, som har stasjon i Oslo, må ha kjøretillatelse av politiet«. Selv om kravene til sjåfører har blitt stadig mer detaljerte i perioden mellom 1980 til 2012, har endringene fra 1930-tallet fram til i dag vært overraskende små etter vår oppfatning. Dette sett i perspektiv av et omfattende mediefokus på lovbrudd i drosjenæringen etter 2003 (Lundgren Sørli 2012) der fokuset på kontroll av sjåfører har vært betydelig. Et eksempel på en relativt ensartet regulering er grunnlaget for utstedelse av kjøreseddel. Per 2012 utstedes kjøreseddel av politiet til sjåfører som har fylt 20 år, har gjennomført kursing og kjentmannsprøven i et område, ${ }^{11}$ akkurat som det var på 1930-tallet. Riktignok er 
kurset potensielle sjåfører skal gjennom vesentlig utvidet, men reguleringen av sjåførenes »adgangs vilkår « er fortsatt bare endret marginalt. Imidlertid er det ikke dermed sagt at dagens sjåførers hverdag ikke er mer regulert enn den var på 1930-tallet, selv om reguleringen bærer preg av å være ganske detaljstyrt. Et eksempel på dette er kravene til sjåførenes uniformering. Noen år ut på 1980-tallet besto fortsatt all påkrevd uniformering at drosjesjåfører måtte bære ei "sjåførlue«. Per 2012 har samtlige sentraler lovfestet uniformsplikt. ${ }^{12}$ Regulatorer av disse bestemmelsene er i hovedsak drosjeeierne og sentralene som med jevne mellomrom gjennomfører stikkprøvekontroller, men publikum er også ment å skulle bidra til opprettholdelse av disse reglene. Oslo kommune opprettet i 2009 en klagetelefon der »Publikum som vil klage på en drosjefører på bakgrunn av ubehagelig oppførsel, nekt av tur osv. kan ta kontakt med Næringsetaten som løyvemyndighet.« (Næringsetaten 2009). Klagetelefonen kunne også brukes av publikum som eksempelvis vil klage på sjåførers uniformering eller kroppslukt.

Ser vi på reguleringen av drosjeløyver, altså inngangsreguleringene til å bli drosjeeier, har denne blitt vesentlig mer omfattende. Også denne reguleringsformen kan føres tilbake til 1933. Eier av en drosjeautomobil måtte ha bevilling fra politiet og antallet (drosjeautomobiler) i Oslo skulle ikke overstige 100, i følge Oslo Taxi (1996:21). Praksis de siste 30 årene er fortsatt basert på de samme prinsipper; fylkesvise løyvekontoret fordeler løyveantall (antall drosjebiler som maksimalt kan være operative i et løyvedistrikt) etter at politiske myndigheter har vedtatt maksimumsantall i distriktet. For å skaffe »drosjeløyve«, i dag definert som en personlig rett og plikt til å drive transport utenfor rute med motorvogn registrert for inntil åtte sitteplasser i tillegg til førersetet ${ }^{13}$ og kunne ta betaling for dette, må en i dag i tillegg ha god vandel, tilfredsstillende økonomisk evne og tilstrekkelig faglig kompetanse. I søknad om drosjeløyve skal det vedlegges ansiennitetsbok, lønns- og trekkoppgaver eller kopi av selvangivelser i tillegg til originalt vitnemål for godkjent løyvekurs som viser bestått faglig teoretisk løyveutdanning godkjent av samferdselsdepartementet. En må videre levere egenerklæring om oppheving av taushetsplikt mellom likningsmyndigheter, politiet og Oslo kommune. En må også stille garanti fra bank eller tilsvarende på 77.000 kroner for det første løyvet og kr 43.000 kroner for løyver utover dette. Avslutningsvis må politiattest samt attest fra konkursregisteret i Brønnøysund vedlegges søknaden.

Det hevdes at den økonomiske organiseringen av drosjemarkedet har blitt deregulert. At stadig flere konkurrerende sentraler er etablert i Oslo-området ${ }^{14}$ og flere aktører konkurrerer på samme marked defineres ofte som økonomisk »deregulering«. Dette innebærer i praksis at konkurrerende sentraler har erstattet mo- 
nopol-situasjoner både i byer og i landet for øvrig. Oslo Taxi var eneste sentral i Oslo-området og Asker og Bærum Taxi kjørte nettopp i Asker og Bærum med en og annen »bytur« til Oslo og etter hvert til Gardermoen da Østlandets hovedflyplass ble anlagt der i 1998. Etter den økonomiske »dereguleringen« av drosjenæringen er moderne drosjetrafikk i de større byene administrert av konkurrerende sentraler som fordeler turer og sørger for kommunikasjon mellom kunder og drosjebiler. Drosjene i bytrafikk er alle knyttet til sentraler. Dette er en særegen norsk utgave av dereguleringen som har skjedd i de fleste europeiske land, i følge Bekken (2003:37). Han karakteriserer resultatet av de norske endringene som »fare deregulation with quantity control $\ll$ og skisserer at »the regulation of fares has been revoked in some urban areas, whereas the number of taxis is still regulated. Fares have only been liberalised in areas where there are competing dispatch centers.« (Bekken 2007:51) Det norske markedet er preget av at det er overskudd på drosjer, og dette må sees i sammenheng med den politiske reguleringen av løyveantallet. Nye løyver tildeles ut fra politiske kriterier (Bekken 2003: 41), uten at behovet i markedet vurderes eller om gjennomsnittet av turer per bil tilsier at det er mulig å drive drosjetrafikk med et legalt overskudd.

Den norske varianten av økonomisk deregulering innebærer med andre ord at man har økt antallet konkurrenter, og strammet inn kravene til aktørene på et ganske gjennomregulert marked. Når det gjelder aktørene i drosjenæringen er deres handlingsrom regulert på et relativt detaljert nivå, mens flere konkurrerende aktører er tillatt. Utover 2000-tallet fortsatte denne utviklingen, antallet sentraler er øt til seks i 2012 og kravene til drosjeeiere ble intensivert. I lovforslag til ny samferdselslov våren 2012 foreslås det at drosjeeiernes »selvpålagte« oppheving av taushetsplikt mellom likningsmyndigheter, løyvemyndigheter og politi (skissert over), blir lovfestet. Konsekvensen er at potensielle skattelovbrudd i framtiden resulterer i direkte rapportering til løyvemyndigheter og at løyver inndrages når overtredelser oppdages. ${ }^{15}$ I tillegg har domstolene i perioden tatt i bruk lovens maksimumsgrense for brudd på regnskaps- og skatteloven. ${ }^{16}$ Oppsummerende kan en si at reguleringen i næringen de siste tre tiårene har blitt mer detaljert og gjennomgripende, til trass for at den ofte fremstilles som et frislipp og en liberalisering.

\section{Policing og overvåking av handlinger gjort i næringssammenheng}

»Policing « eller polisiær virksomhet kan forstås som ulike former for forsøk på opprettholdelse av orden og sikkerhet ved bruk av overvåking og trussel om sanksjoner, Reiner (2000:3). Det er ikke utelukkende politiet som driver med denne formen for ordensopprettholdelse, men en rekke ulike sivile, offentlige el- 
ler halvoffentlige aktører (Larsson og Gundhus 2008). En del av den polisiære virksomheten skjer ved »overvåkning « av næringen, ved både intern og ekstern kontroll av dens arbeids- og omsettingsmarked.

Denne formen for policing kommer til uttrykk gjennom drosjeselskapenes interne rutiner for rapportering og dataoppbevaring, rapportering av kjørerapporter og omsetting til myndighetene. Reglene er innskjerpet betydelig, via kommunale forskrifter, det siste tiåret og innstrammes ytterligere i det nye nasjonale utkastet til Samferdselslov. Dette kan forstås som en overføring av overvåkingsansvar fra politiske myndigheter til næringen selv. Samtidig er det klart at brudd på regler og mangel på oppfølging av krav som stilles vil sanksjoneres og straffes, tildels strengt. Aftenposten $\left(2008^{17}\right)$ slår opp at Oslo kommune den 10. februar offentliggjorde de første konkrete tiltakene mot drosjenæringen etter de mange svindelsakene de siste årene. De konkrete tiltakene presenteres som strakstiltak, »byråd lover bransjen hestekur« i følge Aftenposten og næringsbyråden Anette Wiig Bryn ${ }^{18}$ siteres på at $»$ Drosjebransjen skal inn i strengere former snarest mulig. Vi har ikke tid til å vente på lovendringer.«. Dette kom til uttrykk i en intensivering av kontrollen av næringen, den eksterne overvåkingen og de polisiære virksomhetene rettet inn mot å kontrollere opprettholdelsen av orden i næringen. Det skjedde i form av strengere kontroll med hvor sjåfører bor, ${ }^{19}$ med innvilgete bestyrerordninger, styrking av samarbeid mellom politi og Oslo kommune ${ }^{20}$ samt opprettelsen av et forum for informasjonsutveksling om drosjenæringen. ${ }^{21}$

Tendensen over tid er at overvåking og polisiære virksomheter rettet inn mot innrapportering av inntekter og overholdelse av rapporteringsrutiner i drosjenæringen har forandret seg ved at den interne kontrollen er styrket og næringsaktører får stadig mer ansvar for overvåking og rapportering fra egen næring og arbeidshverdag. Dette kan forstås som et ledd i compliance-bygging, Croall (2001: 117) og Graborsky \& Braithwaite (1986). Compliance kan i denne sammenheng oversettes med oppfølging og implementering av regelverk. Mye av dagens regulering retter seg mot at næringslivet iverksetter selvregulering. En vesentlig del av de ulike tilsynsmyndighetenes arbeid med regulering av næringslivet er å tilse at dette følges opp. Mye av den sanksjonering som skjer i dag retter seg derfor ikke mot lovbruddene selv, men mot manglende oppfølging av krav, eksempelvis når det gjelder sikkerhet og rapportering av avvik, gitt i regelverk (Larsson 2012).

Når det gjelder den eksterne kontrollen av svart arbeid og konsekvenslovbrudd i drosjenæringen kan vi ta utgangpunkt i to områder som for drosjenæringens del har vært sentrale for kontrollen (inkludert overvåkningen) av næringen. De eksterne kontrollformene med næringen er utviklet over tid når det gjelder kontroll med biler, fart og taksametre. Kontrollen av biler og hastighet i drosje- 
næringen har fram til 2000-tallet fulgt den generelt økte overvåkningen av bilparken. Video-overvåking av hastighet og EU-kontroller med kjøretøy gjelder også biler brukt til drosjeferdsel. Sikker Trafikk (2012) melder at de første fotoboksene til bruk av fartskontroll på norske veier ble satt opp i 1988, at det i 2008 var 398 fotobokser fordelt over hele landet og antallet var planlagt økt. Forskrift om periodisk kontroll av kjøretøy (2009) ble første gang vedtatt i 1997, har stadig vært endret $\mathrm{i}$ retning av mer detaljerte bestemmelser i tiden etter og gjelder i dag de aller fleste kjøretøy på norske veier, inkludert drosjer. I tillegg til den allmenne kontrollen med biler og fart blir drosjebilers taksametre og kilometerstand kontrollert årlig av Justervesenet. Kontrollen med taksametre og kilometerstand ble innført i løpet av en overgangsperiode fra 2010 og skulle være gjennomført for samtlige biler fra 1. januar 2012. Justervesenet (2012) melder at »(b)akgrunnen for de nye kravene var blant annet å sikre et bedre grunnlag for skatterapportering, samt ønske om bedre kontroll på taksametrenes måletekniske egenskaper«. Som nevnt blir også data fra drosjebilenes GPS'er, i korthet bestående av oversikter over kjørestrekninger og fart for den enkelte bil, i flere sentraler direkte overført til lagring i sentralenes databaser, og gjort tilgjengelig for offentlige kontrollører når for eksempel politiet eller likningsmyndighetene har legal tilgang til informasjonen.

Med andre ord er grunnlagsmaterialet for kontroll med omsetning, kort sagt materiale produsert ved kontroll og overvåking av de materielle forutsetningene for å drive med drosjekjøring ${ }^{22}$-bil, fart, kjørelengde og taksametre - delvis produsert ved den automatiske overvåkingen som kontinuerlig gjennomføres med alminnelig bilpark og fart. I tillegg kontrolleres næringsaktører via data som automatisk lagres i sentralenes dataarkiver og via Justervesenets årlige kontroller med kilometerstand og taksametre. Materialet er omfattende og offentlige kontrollørers tilgang til materialet forenkles via reguleringsendringer.

\section{Skattekontroller}

En drosjeeier med mer enn 30 års fartstid kommenterer tilstandene på 1980-tallet ved å si at »Lite gikk etter boka men vi fikk da løst de problemene som oppsto!«. Hans poeng er at man ordnet opp i det som måtte ordnes opp i, også rapportering til myndigheter og skattebetaling, slik at resultatet så noenlunde greit ut. Om virkemidlene var ulovlige, spilte det lite rolle så lenge overflaten ikke ble ripet for mye i.

At det ikke ble utført inngående kontroller av næringen skattevilje på 1980tallet, er ikke overraskende. Det var i det hele tatt ikke vanlig at skattemyndighetene utførte kontroller ved å gå inn i bedrifter og næringer. En av de første gange- 
ne skattemyndighetene fysisk gikk inn i bedrifter og startet »etterforskning « etter mistanke var ved de såkalte banksertifikatsakene i 1989/90 i følge Larsson (2002). Den aktive rolle skattemyndighetene tok overfor ulike næringer, eksempelvis frisør- og utelivsbransjen på 1990-tallet innebar langt på vei en ny arbeidsmåte. På 1990-tallet festet norske likningsmyndigheter for alvor kontrollgrepet. Økonomisk kriminalitet og skatteunndragelser ble satt på dagsorden i forbindelse med den økonomiske krisen 1989-92 og drosjenæringen var allerede under mistanke. Kontrollen med drosjenæringen bidro til at underrapportering av inntekter ble kartlagt ut fra et utvalg av drosjebileieres omsetting. Imidlertid ble næringen ikke kontrollert inngående mer etter at skatteinnbetalingen etter 1994 økte vesentlig. Da hadde likningsmyndighetene understreket at bokettersyn ville iverksettes hos de som ikke innrapporterte økte inntekter. Likningsmyndighetene var da rimelig optimistiske, og mente næringen var under kontroll.

Etter aksjonen mot regnskapsføreren (i 2003) kontrollerte likningsmyndighetene og Skatt Øst igjen omsetting gjennom to faser, fase 1 oppgitt inntektsgrunnlag for skatteårene 2000-2003 og fase 2 tilsvarende for årene 2004-2006. Man konkluderte med at mer enn 100 millioner skattekroner var unnlatt innbetalt, og at en rekke sjåfører hadde hevet trygd mens de hadde arbeidet svart i næringen. Dette bare i Oslo-området.

Kort oppsummert vil vi peke på at den interne kontrollen i næringen er intensivert. Den enkelte drosjeaktør og materialet hun trenger for å gjøre jobben overvåkes i dag ganske inngående og da særlig ved at interne kontroller og overvåking medfører at betydelige mengder med informasjon samles om den enkelte drosjesjåfør, -eier og -bil. Man har i dag har et langt større kontrollpotensial enn tidligere og de reguleringsmessige endringer går i stor grad ut på å øke ulike polisiære virksomheters legale tilgjengelighet til lagret datamateriale. Spørsmålet blir da som alltid hvor gode dataene er når de skal brukes praktisk i forbindelse med kontroll, deres kvalitet og hvor enkle de er å fremskaffe. Mye data er ikke nødvendigvis det samme som gode data.

\section{Hvordan kan situasjonen i drosjenæringen forstås?}

Reguleringen av drosjenæringen reiser flere interessante spørsmål. Man kan si at næringen deler grunnleggende trekk med andre der kostnadene for å komme inn kan være relativt lave, man har hatt en kontantøkonomi og få krav til formell utdanning. Disse trekkene peker i retning av at den svarte økonomien burde være betydelig. Med økt konkurranse og en mulig overetablering har man fătt inn et annet element som ofte forklarer økonomisk kriminalitet (Coleman 1987, Larsson 1995). Det finnes klare push og pull faktorer som trekker i retning av fusk og re- 
gelbrudd (Larsson 2002). Når man på toppen av dette legger til at næringen selv har en tradisjon med manglende avstandstaken til småfusk (Ellingsen 1991, Lundgren Sørli 2008 og 2011) og har oppfattet den offentlige kontrollen som svak (Lundgren Sørli 2012) så burde man ikke overraskes over det man finner.

Noe av det mest interessante er myndigheters og mediers pågående fokus på svarte inntekter i næringen de siste tiår. Drosjenæringen var blant de som skattemyndighetene hadde i siktet allerede på slutten av 1980 tallet (Ellingsen 1991 og Lundgren Sørli 2012). Spørsmålet er hvordan det da kan ha seg at vi i drosjenæringen fikk tidenes absolutt største norske skattesak etter årtusenskiftet?

Haakaas og Sæther (2010) understreker i sin bok om svindelsaken det etniske aspektet, at en overveiende del av sjåførene og eierne hadde pakistansk bakgrunn. Deres bakgrunn skulle medføre at de hadde en annen skattemoral. Deres syn på staten fremheves som unorsk i betydningen at de oppfatter staten som en aktør som kun tar uten å gi noe særlig tilbake. Det er mulig dette kan ha verdi for å forklare noen av de største aktørenes handlinger, men det er nok eksempler på at også ikke-pakistanske aktører var sentrale og svindlet i stort omfang. Den mest sentrale aktøren i utviklingen av unndragelsesopplegget til et omfattende system var heilnorsk, flere av hans kunder norske eller med annen nasjonalitet enn pakistansk.

Et annet spennende moment er at den som utviklet skatteunndragelsesoppleggene i Oslo til finesse hadde bakgrunn fra kontrollapparatet. Dette aspektet er ikke uvanlig i internasjonale studier av økonomisk kriminalitet, men er så vidt vi vet relativt uvanlig i Norge og Sverige. Om dette har sammenheng med at det virkelig er få myndighetspersoner med kontrollbakgrunn som utfører økonomiske lovbrudd eller om det er slik Lindgren (2000:111) påpeker: I forskningen på økonomiske lovbrudd »fokuseras knappast en mer renodlad yrkesbaserat brottslighet i form av exempelvis läkares, advokaters, polisers, revisorers, kommunala tjänestemäns, ombudsmäns och politikers lagöverträdelser « skal vi ikke diskutere her. Når det gjelder den konkrete saken i drosjenæringen, kan intervjuer imidlertid tyde på at handlingene og den systematiske organiseringen av lovbrudd $i k k e$ hadde blitt mistenkt og etterforsket dersom ikke hovedmannen hadde vært kjent $\mathrm{i}$ kontrollapparatet før han gikk ut av det. Norge er et lite land. Når et alminnelig tilgjengelig og hyppig gjentatt argument for å kjøpe en tidligere offentlig tjenestemanns tjenester var hans kjennskap til lover og kontrollsystem som skulle gi drosjeeiere lavere skatt, var det lite overraskende at mistanke ble vekket.

Sett ut fra et situasjonelt perspektiv kan det synes som man her har med et klassisk eksempel på en såkalt omfordelingseffekt og en tilpassning til et nytt kontrollregime. Selv om det kom inn mange nye aktører på drosjemarkedet i lø- 
pet av de siste 20 årene, synes det som det likevel er en kontinuitet $\mathrm{i}$ unndragelsene. Når Ellingsen anslår at minimum $50 \%$ av omsetningen i næringen var svart på 1980 tallet så skal det mye til for å forandre dette radikalt. Med Johansen (1991) kan man snakke om en tradisjon for unndragelser. I Larsson sin studie av frisørenes skatteunndragelser (1995) viste han klart at det ble oppfattet som en normal del av driften og som en belønning å putte deler av omsetningen »rett $\mathrm{i}$ lomma«. Unndragelsene fikk man inn med morsmelken ved at man lærte seg det som en del av yrket under praksisopplæringen. Dette er også funnet i svensk og norsk langtransport, (Pettersson 2009 og Lundgren Sørli 2005). Mye tyder på at det samme gjelder for andre håndverksyrker og Lundgren Sørli (2008) har påpekt at unndragelsesmodus også i drosjenæringen har historie og har blitt spredt mellom etablerte og nyere drosjeeiere og sjåfører.

Med utgangspunkt $i$ et situasjonelt perspektiv som understreker at lovbrudd vil skje om det eksisterer muligheter for lovbrudd og man har motiverte aktører så kan en se at regulering i seg selv sjelden er nok til å skape lovlydighet. Reguleringen kan gjøre det vanskeligere og mer risikabelt å begå lovbrudd, men er gevinsten og motivasjonen sterk nok går det ofte galt. I drosjenæringen foreligger det en del kriminogene faktorer som bidrar til at motivasjonen for å kjøre svart har holdt seg høy over en årrekke. En del av disse kan karakteriseres som strukturelle, altså med årsak i strukturene næringene arbeider innenfor, og er identifisert av Lundgren Sørli (2011). Et eksempel som går igjen i flertallet av intervjuer med drosjeeiere og bileiere, er at de oppfatter det i drosjenæringen vedtatte løyveantallet som for høyt til at en drift i overensstemmelse med lovverk og regelverk kan være lønnsom. Oppfatningen har så bred tilslutning at den bidrar til å strukturere handlingsvalg for de i bransjen. Slik »er« verden - og drosjeaktører handler ut fra det. Dette gir seg konkrete utslag i at det utøves et visst press på sjåfører fra enkelte eiere om å kjøre svart, men også fra dyktige sjåfører på drosjeeiere om å få kjøre svart (Lundgren Sørli 2008).

Nå kan det selvsagt, som Haagensen \& Johansen (1991:18 ff) gjør, stilles spørsmål om økonomiske lovbrudd i særlig grad begås av vanskeligstilte bedrifter. De viser til en undersøkelse av saker om økonomiske lovbrudd som ble domstolsbehandlet i Norge på 1980-tallet. Økonomisk vanskelige forhold kan legge grunnlaget for noen typer økonomiske lovbrudd, men må sees i sammenheng med andre faktorer. Dette stemmer bra med Clinard og Yeagers (1981) samt Shaw og Szwajkowskis (1975) funn. Vi vil også slutte oss til dette argumentet. Selv om oppfatningen av at det er så vanskelig å skaffe overskudd ved legal drosjedrift at det enkleste er å kjøre svart, er utbredt, er den ingen »universalforklaring« på at drosjeeiere og sjåfører fortsatt kjører svart i drosjenæringen. For 
det første finnes det også i norsk sammenheng flere eksempler på omfattende skatteunndragelser innen høystatusyrker hvor inntektsnivået er høyt, som blant leger og tannleger.

For det andre er det kanskje viktigere at oppfatningen forståes som det Coleman (1989: 205, sitert i Haagensen \& Johansen 1991: 18) formulerer som »a part of a larger motivational complex«. I drosjenæringen har det over tid vært en situasjon der man har hatt et klart og ferdig »opplegg « - som gjorde det enklere å unndra midler både teknisk og motivasjonsmessig. Tradisjonelt har man byttet mellom svarte og hvite taksametre. I nyere tid, fra 1990-tallet etter innføringene av de digitale taksametrene, har det vært tilgjengelig informasjon om hvordan man med noen tastetrykk fjerner kontantinnkjørt fra dagsinnkjørt. Det kan også se ut til at kunnskap om regnskapsførerens mer organiserte skattesvindel ved forfalskning av regnskap og kjørerapporter var utbredt blant en del drosjeaktører. Når teknisk innsikt åpner for lovbrudd, kunnskapen spres mellom aktørene og motforestillingene mot å utføre lovbrudd i en del grupper er rimelig minimal, kan man si at grunnen for at lovbrudd gjøres var rimelig godt beredt i drosjenæringen også på 2000-tallet.

Imidlertid har det skjedd ting i næringen. Drosjeaktører signaliserer på 2000tallet også at de ønsker mer kontroll og en fungerende regulering av næringen. Bakgrunnen til det er at man antar at mer kontroll vil redusere lovbruddene i næringen. Sosialt avvik, kriminalitet, forstås som et resultat av at sosial kontroll ikke fungerer (Parsons 1951, Sumner, 1994, 1997). Når ønsket om økt og intensivert kontroll etterspørres som svar på at lovbrudd oppfattes som et stort problem, kan det sees som et ønske om det Levi karakteriserer som »increasing the risks of detection and salient sanctions, and redusing oppurtunities« (Levi 2001:74). Denne forståelsen står sterkt både blant drosjeaktører og myndigheter som arbeider med næringen og det er helt klart at forståelsen ikke er uten rot i virkeligheten. En rekke empiriske studier viser at det er sammenhenger mellom risiko for oppdagelse og økonomisk lovbruddsaktivitet, se for eksempel Eide (2000) som gir en god oversikt.

Vi vil likevel understreke, som også Michael Levi gjør (Levi 2001 og 2009), at tilnærming $\mathrm{i}$ form av økt oppdagelses- og sanksjonsrisiko ikke er den eneste tilnærmingen egnet til å skape større grad av lovlydighet i næringslivet. Innen drosjenæringen er det neppe mangler ved reguleringen i seg selv som bidrar til at unndragelsene ikke er stoppet. De senere år har myndighetene forsøkt å innføre et reguleringsregime som skal forhindre eller i alle fall vanskeliggjøre unndragelser. Når det så har blitt utviklet et omfattende system for å omgå dette blir reaksjonene fra myndighetenes side ikke uventet strenge. Dommen på 8 års fengsel er 
uvanlig streng etter norske standarder for økonomiske saker. Det er flere forhold som gjorde utslag. Noen er nevnt i dommen, omfanget var meget stort og opplegget var rasjonelt utviklet for å svindle staten av en tidligere betrodd. Dommen vitner om hva Ayres og Braithwaite $(1992,2009)$ kaller »the benign big gun « det vil si »den snille storslegga«. Poenget er at regulering av næringslivet, selv om det til stor del hviler på compliance og selvregulering, må ha en reell straffetrussel i bakhånd. Man bruker gulroten så langt råd er, men uten et ris bak speilet i bakhånd har »the sweet talk« lite å stille opp med. Straffen er et uttrykk for akkurat dette.

Med andre ord er regulering gjennomført og polisiære virksomheter innført med sikte på å ta kontroll med lovbruddene i drosjenæringen, slik vi ser det på en helhetlig og systematisk måte. Likevel har drosjeaktører fortsatt å utøve lovbrudd. I forlengelsen av dette oppstår et spørsmål om hvorfor det er så vanskelig å regulere noen bransjer på en god måte.

\section{Hvorfor er det så vanskelig å regulere drosjenæringen?}

For å kunne svare på hvorfor det har vært så vanskelig å regulere drosjenæringen, finner vi at noe av forklaringen ligger i drosjeaktørers forståelse av lovbrudds nødvendighet. Giddens (1984) bidrag om »duality of structure«, at strukturer må forstås som todelte ved at de er »both the medium and the outcome of the practises which constitute social systems« underbygger denne forståelsen. Strukturer blir altså summen av de rammene vi lever innenfor $\mathrm{OG}$ vår forståelse av hvordan disse påvirker oss og hvordan det henger sammen. James Messerschmidt påpeker at "people participate in self regulating conduct whereby they monitor their own and other's social action « (Messerschmidt 1997:5). Dette påvirker individets tilbøyelighet til å gjøre lovbrudd. Arbeider en i sammenhenger der en oppfatning av at lovbrudd ikke gjøres/ er unødvendige, dominerer, er det nærliggende å tro at terskelen for lovbruddsaktivitet er relativt høy. På den annen side kan lovbrudd læres, som en integrert del av ens yrkesutøvelse (Larsson 1995). Svartkjøring kan derved bli en aktivitet som mange oppfatter som normalt i forlengelse av yrkesutøvelsen. Kanskje har man fokusert for mye på svartarbeid som et brudd, som atypisk, mens det i realiteten kan være en innarbeidet del av hvordan næringen fungerer. Mye kan derved tyde på at regulering ikke har fătt direkte konsekvenser i form av redusert lovbruddsaktivitet i drosjenæringen blant annet fordi man ikke har maktet å påvirke aktørenes motivasjon og oppfatninger.

Man kan også spørre om det er noe ved den kontrollpluralismen som i praksis er satt i verk i drosjenæringen som bidrar til at drosjeaktørers lovbruddsaktivitet fortsetter? Det er i følge David M. Kennedy et velkjent, men vanligvis ignorert 
poeng at dersom lovbrudd skal forebygges effektivt, må forebyggende tiltak være i overensstemmelse med »hva som betyr noe for lovbrytere og potensielle lovbrytere« (Kennedy 2009: 22). Med andre ord må forebygging ta utgangspunkt i lovbrudds betydning for den enkelte aktør. Skal svart kjøring og andre økonomiske lovbrudd forebygges, må en, fordi handlingene har en form for vinningsmotiv, sørge for at gevinsten av lovbruddene framstår som mindre enn den potensielle prisen ved at lovbrudd oppdages, etterforskes og sanksjoneres. Etter vårt syn er dette sannsynligvis å forenkle både utforming og effekten av regulering og kontroll noe, særlig dersom en ser på det »batteri av innsatser« (Lindgren 2000: 169202), eller det konglomerat av virkemidler som er satt inn mot økonomisk kriminalitet i skandinavisk sammenheng generelt og i drosjenæringen spesielt. Imidlertid er det et poeng, regulering og kontroll må nok, som vi har vært inne på, oppleves både som en gulrot $o g$ et reelt ris bak speilet dersom den skal kunne være effektiv (Ayres og Braithwaite 1992).

Perspektivet er også interessant fordi det reflekteres i skattemyndighetenes svar på spørsmålet om hvorfor reguleringen ikke har fătt bukt med problemene i drosjenæringen. De poengterer at regulering ikke er fulgt opp med effektiv håndheving, og at »oppdagelsesrisikoen« ved lovbrudd i drosjenæringen tradisjonelt har vært symbolsk nærmest mikroskopisk. Spørsmålet om hvorfor det er slik har til dels et pragmatisk svar, et effektivt håndhevelsesapparat koster penger og ressurser. Jo mer finmasket nettet av polisiære virksomheter og overvåkingen skal være, desto mer ressurser går med til å opprettholde det. Sett fra et samfunnsøkonomisk perspektiv er det grenser for hvor lenge et nett av finmasket reaktiv kontroll og overvåking kan opprettholdes for å få inn noen skattekroner. Et annet moment er at få ønsker et slikt kontrollapparat. Dagens regulering oppfattes allerede av mange både innen næringslivet og politikken som for omfattende. I andre næringer (f.eks. skandinavisk langtransport iflg. Pettersson (2009) og Lundgren Sørli, 2005) har vi også sett at regulatorers innsats reduseres over tid, blant annet i takt med at kontrollører og polisiære virksomheter får nye oppgaver, prioriteringer og fokus endrer seg når få regelovertredelser oppdages i en gitt periode.

Lotta Pettersson (2012) diskuterer om kontroll i seg kan forståes som en kriminogen faktor, med hennes egne ord spør hun om »kontroll kan rättfärdiga brott« (s. 143) og konkluderer på bakgrunn av et studium av svensk langtransport at ja, kontroll oppleves i denne næringssammenhengen som ekstra vanskeliggjøring av en allerede tung hverdag, som kan forenkles ved lovbrudd og kreative konsekvenslovbrudd. Kontroll kan med andre ord framstå som en av flere parallelle kriminogene faktorer. ${ }^{23}$ Langtransporten er en mannsdominert næring der det å lure kontrollører i seg selv har en maskulinitetskonstruerende effekt og en 
egen verdi (Lundgren Sørli 2005), og Petterssons konklusjon må sees i lys av dette. Med andre ord kan kontrollens betydning ikke uten videre overføres til aktører i andre næringer. Imidlertid er spørsmålet interessant også for drosjenæringen, dersom det spissformuleres til hvorvidt reguleringen og kontrollen av næringen kan være en medvirkende faktor til lovbrudd. Vi har beskrevet en utvikling der økt regulering og overvåking har fått svar i form av mer organiserte og strukturerte svindelmetoder. Utviklingen har gått fra mekaniske svarte og hvite utskiftbare taksametre til dataprogrammer og forfalsket regnskapsmateriell. Man snyter fortsatt staten og felleskapet for skattemidler, men konsekvenslovbruddene som har blitt nødvendige for å skjule unndragelsene har blitt flere, mer kompliserte, systematiserte og i seg selv gjenstand for regulering og kontroll. Imidlertid synes det ikke å ha gått sport i å lure regulatorer og kontrollører slik det har i langtransporten, mye kan derfor tyde på at regulering og kontroll primært fører til økt registrering av den kriminaliteten som gjøres. At lovbruddene i drosjenæringen hadde vært vesentlig flere dersom reguleringen og overvåking av næringen ikke hadde vært forsterket de siste 30 årene, er likevel nærliggende å tro.

\section{Noter}

1. Paul Larsson er professor i kriminologi ved Politihøgskolen i Oslo og gjesteprofessor i Politivitenskap ved Linnéuniversitetet i Växjö. Han var tidligere stipendiat ved Institutt for kriminologi og seksjonssjef for analyse og forebygging i Politidirektoratet. Publikasjoner dekker feltene økonomisk og organisert kriminalitet, kriminologisk teori og studier av politi.

2. Vanja Lundgren Sørli is PhD in Criminology from University of Stockholm and works as associate professor at the Police Academy and University of Oslo, Norway.

3. I begrepet regulering inkluderer Larsson også »governing « og »kontroll«. I denne artikkelen vil vi være mer eksplisitte på to av de tre aspektene, vi forholder oss til kontroll og regulering selv om det innebærer et analytisk mer enn et reelt skille mellom regulerings-aspektene.

4. Fra politiets Økokrim til NAVs misbruksteam

5. Tilsvarer svart, det vil si at inntekter fra denne virksomheten ikke er innberettet skatt av.

6. Noe Oslo Taxi løste ved å lage et digitalt taksametersystem som senere ble modell for tilsvarende systemer i en rekker byer både innenlands og utenlands

7. Daværende Rikstrygdeverkets misbruksteam.

8. Sykepenger, uføretrygd, sosialstøtte, bostøtte, $\mathrm{mm}$.

9. Man har etter en tidligere rettsavgjørelse unngått å ilegge aktører »dobbel straff«. Det innebærer at retten spesifikt må bestemme at en person både skal tilbakebetale penger som hun urettmessig har mottatt og fengsles for det samme forholdet, det er ellers ikke lovlig for et administrativt organ både å kreve tilbake penger og samtidig anmelde og be om tiltale av en person for det samme forholdet.

10. Et nytt lovforslag er per mai 2012 ute på høring.

11. I Oslo og Akershus hos Oslo Taxi eller Oslo/Akershus Taxiskole. 
12. Uniformsplikten innebærer at den som kjører drosjen skal har karakteristiske benklær, skjorte, i enkelte sentraler lue med karakteristisk logo som tydeliggjør sentralen man kjører for.

13. Det finnes enkelte unntak for busser i drosjetrafikk som tar flere passasjerer. Løyve for persontrafikk for inntil åtte passasjerer er det vanligste. Kriteriene som gjelder for disse løyvene gjelder også løyve for de større bilene, forutsatt at de går i persontrafikk utenom rutetrafikk.

14. Dette gjelder de fleste større byer i Norge.

15. I skrivende stund må løyver »fradømmes«, det vil i praksis si at en person med drosjeløyve utelukkende kan fratas dette ved dom, død eller høy alder.

16. Se beskrivelsen av »regnskapsfører/drosjesvindelsaken« over.

17. Tilsvarer Aftenposten (2008c) i medieutvalget.

18. Som overtok byrådsansvaret for drosjenæringen den 1. mars 2008.

19. Utført av kommunen i samarbeid med folkeregisteret, kemneren og likningsmyndigheter.

20. Et »taxiteam« ble opprettet for samtaler og samarbeid mellom politiet, kommunen, NAV og likningsmyndighetene men det ble i tiden fram mot 2012 sannsynligvis bare avholdt to møter i dette teamet.

21. Blant annet mellom Skatt Øst og Oslo kemnerkontor.

22. Biler, teknisk utrustning og taksametre.

23. Det er dessuten slik at man må ha regler for å kunne bryte dem. Med et omfattende regelverk vil flere muligheter for fusk by seg, noe som i visse sammenhenger kan gi et konkurransefortrinn. De moralske sperrene for å bryte reglene vil dessuten ofte være lav eller fraværende når de oppleves som »tekniske« lovbrudd, mala prohibita (Larsson 2002).

\section{Referanser}

Alalehto, T. (1999): Motiv eller tilfälle? En studie av ekonomisk brottslighet i restaurangbranschen. Stockholm: ATLAS.

Aftenposten (2012): »Ny gigant-siktelse mot drosjesvindler« av Haakaas, E. I: Aftenposten Morgen, seksjon økonomi 10.05.2012 s 5.

Aftenposten (2009): »Juks og vær glad « av Riaz, W.K. I: Aftenposten Aften 30.09.2009 s. 2

Aftenposten (2008): »Svindlere mister løyvet« av Haakaas, E. \& Sæter, K. I: Aftenposten Morgen. 10.02.2008 s. 3 .

Ayres, I. \& Braithwaite, J. (2009): »The Benign Big Gun«. In: Croall, H. (ed): Corporate Crime.Volume 3: Controlling Corporate Crime. London: SAGE Publications Ltd.

Ayres, I. \& Braithwaite, J. (1992): Responsive regulation. Transcending the deregulation debate. Oxford, Oxford Socio-Legal Studies.

Bekken, J.-T. (2007): »Experiences with (de-)Regulation in the European Taxi Industry« In: ECMT/OECD: Round Table 133: (De-)regulation of the Taxi Industry. Paris.

Bekken, J.-T. (2003): Taxi regulation in Europe. Final Report. Geneva: International Road Transport Union.

Braithwaite, J (2002): Restorative Justice and Responsive Regulation. Oxford: Oxford University Press.

Braithwaite, J. \& Fisse, B. (1987): „Self-regulation and the Control of Corporate Crime«. In: Shearing, C \& Stenning, P. (eds): Private Policing. London: SAGE.

Clinard, M.B. \& Yeager, P.C. (1980): Corporate Crime. New York, London: The Free Press. 
Coleman, J.W: (1989): The Criminal Elite. The Sociology of White-Collar Crime. New York: St. Martins Press.

Coleman, J.W: (1987): Towards an integrated Theory of White-Collar Crime« i American Journal of Sociology.

Croall, H. (2001): Understanding White Collar Crime. Buckingham, Philadelphia: Open University Press.

Eide, E (2000): »Oversikt over litteratur om svart arbeid og skatteunndragelser «. I: Rapport (Frischsenteret). Oslo: Frischsenteret.

Ellingsen, D. (1991): »Svart arbeid i drosjenæringen« I: Johansen, P.O. (red): Studier i økonomisk kriminalitet. Oslo: Institutt for kriminologi, K-serien nr 1-91.

Fisse, B. \& Braithwaite, J. (1993): Corporations, Crime and Accountability. Cambridge: Cambridge University Press.

Forskrift om periodisk kontroll av kjøretøy (2009): FOR 2009-05-13 nr 591: Forskrift om periodisk kontroll av kjøretøy. Oslo: Lovdata.

Giddens, A. (1984): The Constitution of Society. Berkley: University of California Press.

Graborsky, P. \& Braithwaite, J (1986): Of manners gentle: Enforcement strategies of Australian business Regulatory Agencies. Melbourne: Oxford University Press.

Haagensen, K. \& Johansen (1991): »Økonomisk Kriminalitet «. Johansen, P.O. (red): Studier $i$ økonomisk kriminalitet. Oslo: Institutt for kriminologi; K-serien nr 1-91.

Haakaas, E \& Sæther, K. (2010): Svindel uten grenser. En reise i svart drosjeøkonomi. Oslo: Aschehoug.

Johansen, P.O. (2007): »The Come-back Boys of illegal Market« i: van Duyne, P: The dirty linens of illegal entrepreneurships. Nijmegen: Wolf Legal Publisher.

Johansen, P.O. og Christophersen, J.G. (1991): »Forurensning som tradisjon. I: Johansen, P.O. (red): Studier i økonomisk kriminalitet. K-serien nr 1-91. Oslo: Institutt for kriminologi.

Justervesenet (2012): http://www.justervesenet.no/Modules/article.aspx?ObjectType=Article \&Article. $\mathrm{ID}=2639$ \&Category.ID=827. Lesedato 29.05.2012.

Kennedy, D.M. (2009): Deterrence and Crime Prevention: Reconsidering the Prospect of Sanction. London: Routledge.

Larsson, P. (1995): Svarte klipp. Om skatteunndragelser i frisørnceringen. Rapport Norges forskningsråd.

Larsson, P. (2002): I lovens grenseland, Pax, Oslo.

Larsson, P. (2011) »Det farlige næringslivet. Reguleringen av økonomisk kriminalitet i det 21 århundre«, i Alalehto og Larsson (red.) Vinddriven kriminalitet på en vinddriven marknad, Recito förlag, Borås.

Larsson, P. (2012): Regulating Corporate Crime: From penal punishment to self regulation. Journal of Scandinavian Studies in Criminology and Crime Prevention, i trykk.

Larsson, P og H. Gundhus (2008): »Policing i et norsk perspektiv.« i Gundhus, Larsson og Myhrer (red.): Polisiar virksomhet. Hva er det-hvem gjør det?, PHS forskning nr. 7. Politihøgskolen, Oslo.

Levi, M. (2009): „Suite Justice or Sweet Charity? Some Explorations of Shaming and Incapacitating Business Fraudsters « In: Croall, H. (ed): Corporate Crime. Volume 3: Controlling Corporate Crime. London: SAGE Publications Ltd. 
Levi, M. (2001): »What Works in Combating White Collar Crime: Some Reflections « In: Lindgren, S. A (et all): White collar Crime Research. Old Views and Future Potentials. Stockholm: BRÅ-report 2001:1

Ligningsloven. Lov om ligningsforvaltning. Lov av 1980-06-13 nr. 24. Oslo: Lovdata

Lindgren, S.-A. (2000): Ekonomisk brottslighet. Ett samhällsproblem med förhinder. Lund: Studentlitteratur.

Liston-Heyes, A \& Liston-Heyes, A. (2007): »Regulation of the Taxi-industry: Some Economic Background«. I: OECD: »(De)regulation of the Taxi-i industry«. Report of the one hundred and thirtythird round table on transport economics. Paris: ECMT/OECD Publishing.

Lundgren Sørli, V. (2012): »Artikulationer av taxikontroll: Sociala konsekvenser«. I: Pettersson, L. \& Pettersson, T.(red.). Kontrollens variationer. Lund: Studentlitteratur.

Lundgren Sørli, V (2011): Evig eies kun et dårlig rykte? Økonomiske lovbruddsbetydning og forebygging i drosjenceringen. Rapport til Norges Forskningsråd. Oslo: Universitetet i Oslo.

Lundgren Sørli, V. (2008): »Svartkjøring i norsk drosjenæring: Kulturelle forståelser«. I: Disorder in Public Space: Resistence or Crime? Economic Crime, Organised Crime and Corruption. NSfK:s $50^{\text {th }}$ Research Seminar. Forssa (Finland): Scandinavian Research Council for Criminology.

Lundgren Sørli, V. (2005): In a Man's World: tolkninger av lovbrudd gjort i langtransportens yrkeskontekst. Stockholms Univ.: Kriminologiska institutionen, Avhandlingsserie nr 16.

Næringsetaten (2012): http://www.naringsetaten.oslo.kommune.no/drosjeloyver/drosjeklager/01.09.2009. Lesedato 18.05.2012

OECD (2007): ECMT/OECD: Round Table 133: (De-)regulation of the Taxi Industry. Paris.

Oslo Taxi (1996): Oslo Taxi gjennom 75 år. Oslo: Oslo Taxi

Parsons, T. (1951): The Social System. New York: Free Press.

Pettersson, L. (2012): »Kan kontroll rättfärdiga brott?« I: Pettersson, L. \& Pettersson, T. (eds): Kontrollens variationer. Lund: Studentlitteratur.

Pettersson (2009): Frihet under kontroll: Om kontroll i åkerinäringen. Kriminologiska institutionens avhandlingsserie no 28. Stockholms universitet: Kriminologiska institutionen.

Regnskapsloven: Lov om årsregnskap mv. Lov av 1998-07-17 nr. 56. Oslo: Lovdata.

Reiner, R. (2000): The Politics of the Police, Oxford University Press, 3ed.

Shaw, B.W. \& Szwajkowski (1975): »The scarcity Muniticense Component of Organizational Environment and Commission of Illegal Acts«. In: Administrative Science Quarterly Vol 20.

Sheahan, M. and Smith, P. (2003) "Deviance and marginal occupations: The case of taxi drivers«. In: Deviant Behavior, 24: 5, pp 449-466.

Sikker trafikk (2012): http://www.sikkertrafikk.no/Fotoboks.htm. Lesedato 29.05.2012

Skattedirektoratet (2003): Skattedirektoratets melding om endring i lov om merverdiavgift. 19.august 2002, oppdatert 16.oktober 2003.

Sumner, C. (1997): "Social Control: The History and Politics of a Central Concept in AngloAmerican Sociology« In: Bergalli, R \& Sumner, C. (eds): Social Control and Political Order. European Perspectives at the end of the Century. London: Sage Publications Ltd.

Sumner, C. (1994) The Sociology of Deviance: An Obituary. Buckingham: Open University Press.

Straffeloven. (1902) Alminnelig borgerlig straffelov. Lov av 22. mai 1902 nr. 10. Oslo: Cappelen Akademisk Forlag.

Toner, J. (1997): »Towards optimal regulation in the Taxi-industry«. Paper, the $5^{\text {th }}$ Conference on Competition and Ownership in Land Passenger Transport, United Kingdom: Tredbo. 